\title{
NAVIGATING BUSINESS TRANSFORMATION WITH FUTURE-READY MINDSET
}

\author{
Muhammad Azman ${ }^{* 1}$, Intan Delia Rustandi*), and Putri Gayatri**) \\ *) School of Business, IPB University \\ Jl. Pajajaran, Bogor 16151 \\ **) Department of Communication and Community Development, Faculty of Human Ecology, IPB University \\ Jl. Kamper, Babakan, Dramaga, Bogor 16680, Indonesia
}

\begin{abstract}
VUCA Era drives the current business ecosystem significantly to be more complex and experience strong turbulence. This ecosystem also brings the business process based on the customer transformation needs (vibrant, unreal, crazy, and astounding). This condition requires a new way of working to face future challenges. However, most business practitioners still use conventional approaches (fixed mindset) rather than agile mindset. The paper aims to navigate business entities to compound with business ecosystem in era 4.0. The methods used to construct the paper are meta-analysis and integrating simplification theory (IST). To navigate its transformation path, the future ready mindsets - curiosity, explorer, empathy, transformative, experimental, and open mindset - will play a crucial part. Sub-concepts for each of the future-ready mindset have already been mapped and matched up with each VUCA characteristic.
\end{abstract}

Keywords: VUCA, business transformation, business ecosystem, future ready mindset

Abstrak: Era VUCA mendorong ekosistem bisnis saat ini secara signifikan menjadi lebih kompleks dan mengalami turbulensi yang kuat. Ekosistem ini juga menghadirkan proses bisnis berdasarkan kebutuhan transformasi pelanggan (bersemangat, tidak nyata, gila, dan mencengangkan). Kondisi ini membutuhkan cara kerja baru untuk menghadapi tantangan masa depan. Namun sebagian besar pelaku bisnis masih menggunakan pendekatan konvensional (fixed mindset) ketimbang agile mindset. Makalah ini bertujuan untuk mengarahkan badan usaha ke majemuk dengan ekosistem bisnis di era 4.0. Metode yang digunakan untuk menyusun makalah adalah meta-analisis dan integrasi teori penyederhanaan (IST). Untuk menavigasi jalur transformasinya, pola pikir yang siap untuk masa depan - keingintahuan, penjelajah, empati, transformatif, eksperimental, dan pola pikir terbuka - akan memainkan peran penting. Subkonsep untuk setiap pola pikir siapmasa depan telah dipetakan dan disesuaikan dengan masing-masing karakteristik VUCA.

Kata kunci: VUCA, transformasi bisnis, ekosistem bisnis, pola pikir siap masa depan

\footnotetext{
${ }^{1}$ Corresponding author:

Email: muhammadzaman.bogor@gmail.com
} 


\section{INTRODUCTION}

Rapid ecosystem changes affect every business practitioner to make quick decisions and to overcome new problems that may have never been encountered before. Many new phenomena in business that currently require transformation so that companies can continue to exist in the midst of increasingly dynamic environmental changes. Business organizations are challenged by many demands such as globalization, intense competition, rapid technological change, new corporate alliances, changing demographic patterns, leaner organizational structures etc (Nazir, 2017).

The VUCA era disrupted the old arrangements with something other unpredictable, unstable, and complicated. As tsunamis flood of complex change through our lives, organization, and communities, the need to develop greater wisdom, resilience, compassion, and creativity at every level becomes ever clearer. Businesses that are comfortable with the success that have been achieved and overly confident in their best practices that have been carried out by companies that have been successful in that period. Many facts show that large businesses have succeeded in the past, but were unsuccessful later. This was conveyed by a quote submitted by Petter Drucker, "The greatest danger during turbulence is not turbulence; it was to act with logic yesterday ".

In the past Nokia as the holder of most of the largest mobile market share announced was unable to compete because it was unable to adapt to consumer needs. Kodak did not want to innovate and be responsive to changes in the business ecosystem. This event provides an overview of the success of business strategies and previous best practices, not enough to face the challenges of business in this era.

The new attitude and mindset that is more agile and seen looking back into the future is one of the keys to success in the future. Leading and navigating through a complex environment such as VUCA is not only challenging but also requires a set of skills that is far more than just being competent. The world of VUCA demands Cognitive Readiness, Ability to be prepared and Agility to handle any situation that appears to infuriate the status quo (Parween, 2019). This paper aims to navigate business entities to join the business ecosystem in the 4.0 era. Emphaty's role is an important component in establishing relationships (Gentry et al.
2007). Empathy is also a part of emotional intelligence that must be possessed by an effective leader (Bar-On \& Parker, 2000; George, 2000). In line with fast changes that have occurred in almost all aspects of lives, there is an urgent need to have better preparation to establish stronger endurance for long-term sustained survival.

Being aware of VUCA that we are currently facing leads us to reflect and ask several questions to ourselves, "How can we become more adaptive in our lives? How can we prepare ourselves to be ready to work effectively with the VUCA trends?"

One of the steps to be done as the preparation is changing the acronym VUCA as stated above into positive VUCA elements, namely Vision, Understanding, Clarity, and Adaptability that will be useful to guide us well in facing global changes.

The existing VUCA trends are predicted to grow stronger, affecting almost everyone in any community. The trends have awaken various community members and those who want to survive well must develop conditions with adaptive qualities. These include gaining insight, a sense of perspective, and an expanded range of options for how to embrace, respond instead of react, relate, connect, and transform challenging situations. Such adaptive qualities are important if we want to be successful in all sustainability initiatives, either as individuals, organizations, or communities.

As social beings, we depend so much on natural systems. However, these systems have now been changing to be more unreliable and unsustainable. Thus, there is no better choice for us but to learn to thrive, and not just survive. The need for learning trains us to be more attentive, wise, creative, and collaborative. Similarly, through learning processes, we are trained to continually reinventing, redesigning, and optimizing our success either as individuals, families, communities, or organizations.

\section{METHODS}

\section{Literature Review and Hypotheses Development}

First, this template has been tailored for output on the A4 paper size. Insert page number at the bottom of the page for easier reference during the review process. From various literature, it has been stated 
that the themes of "change resilience," "whole systems thinking", "personal and organizational sustainability", "expanding personal capacity", "mind-fitness", "courage", "compassion", and "presence" are getting special attention.

The matrix below illustrates how VUCA Era can disrupt arrangement and the old order with something unpredictable, unstable, and other complex conditions and it takes an attitude and mind-set that are new, more adaptive and transformative. Era VUCA organization urged the perpetrators to businesses to be more responsive to change, intelligent in looking at opportunities and challenges, to have the flexibility to respond to unexpected shocks that could survive in this VUCA era.

Wisdom at Work's Navigation Skills for VUCA Times develop the capacity of leaders and organization to respond wisely to our VUCA times and the world. The results can be measured across both inner (personal) and outer (organizational) spheres of influence. At an organizational level, VUCA-savvy leaders are more aware, adaptive, Courageous, confident and empowered by VUCA forces at work, and are better equipped to deal Effectively with:

- The business of making sense of Reviews their data stream and knowledge management.

- Anticipating and planning for the future.

- Managing critical processes and resources.

- Increasing functional responsiveness and modelling.

- Informing learning loops and process improvements at every level of influence.

- Creating healthy, thriving organizational cultures and inspiring people with the knowledge and skills

Necessary to optimize the flow of make attention and energy at work. At a personal level, VUCA-savvy leaders have greater capacity to:

- Be fully present, mindful, and attentive to the stream of information that flows to them and through them.

- Be more Discerning and realistic regarding attributing meaning to circumstances, and better Able to Recognize both opportunities and Dangers that are present or Likely to emerge.

- Clearly perceive a greater range of Interpretations and options for action.
- Be better-able to maintain Reviews their clarity and balance in the Midst of a highly turbulent circumstances, and Tus be more resilient and adaptable in responding to emerging realities.

- Inspire others to do all of the above through make example.

The elements of VUCA mindset define the context in the which leaders and their organization Reviews their current view of reality and Likely future state. Depending on one's mindset, VUCA elements can either confound decision-making and responsiveness or they can sharpen the capacity to view currently reality with greater clarity and realism, see meaningful interdependencies, skill full respond to current realities, while anticipating consequences, and wisely planning for future courses of action.

Wisdom at Work's Navigation Skills for VUCA Times offers essential learning and inspiration for people aspiring to function skill full, managed wisely, respond compassionately, and lead resiliently In These turbulent times[http://www.wisdomatwork.com/about/thrivingin-vuca-times/].

Human Development Index is the most concrete tool for measuring competencies, expertise needed and knowledge of human resources in a country. Countries that have a high enough index has men with higher competence compared with other countries with a lower index.

Indonesia Human Capital Index ranks 111th of 189 countries in the world (the United Nations Development Program, 2019) with the value of the Human Development Index (HDI) for 0707 was far below Norway, Switzerland and Ireland as the country with the highest HDI rating in the world each respectively for 0.954, 0.946, and 0.942. In Southeast Asia, Indonesia is under Singapore, Philippines and Malaysia.

This is unfortunate because on the other side of Indonesia has the third largest population of world of course much quantity is not enough being offset by good quality. Transformation required improving the quality of human resources in accordance with the times, especially in this VUCA era. In preparing for a strong Human Development Index, Upgrading Future Ready Mindset is the key to instilling values, motives, to behave the soft competencies in mapping (navigate) the human resources in progress. 
Micro, Small and Medium Enterprises (SMEs) is one of the strengths of Indonesia. As one of the driving wheels of the economy since the first until now. This is evident when SMEs managed to survive the crisis of 1998. According to BPS data in 2018 SMEs have a central role in the economy in Indonesia. A total of 64.1 million units SMEs accounted for around $60.9 \%$ of GDP and provides jobs for the community of $96.82 \%$. SME development continues to increase each year.

According to Steinhoff and Burgess (1993), in Suryana (2003), entrepreneur is someone who organizes, manages and dare to bear the risk of creating new businesses and business opportunity "A person who organizes, manages, and assunes the risk of a business or enterprise is an entrepreneur, the entrepreneur is an individual who risks financial, material, and human resources a new way to create a new business concept or opportunities within an existing firm ".

Then Prominent features in the entrepreneurial characteristics are: Temperance (Self Control): They want to be able to control all their did.

- Managing by objectives (Manage by Objective): They quickly understand the task details that must be completed to achieve their goals

- Analyzer opportunities (Opportunity Analyzers): They will analyze all option to ensure success and minimize risk

- Creative thinkers (Creative Thinkers): They will always find a way good at doing something

- Trouble shooter (Problem Solvers): They will always look at options for Problems to solve any blocking on the road

- Thinkers objective (Objective Thinkers): They are not afraid to admit when they are wrong (Riyanti, 2003)

Unfortunately, businesses, especially SMEs still have financial problems (79.8\%), working capital constraints (61.7\%), marketing constraints (55.3\%), the constraints of location $(31.9 \%)$ and raw material constraint factor (8.5\%). (Bank Indonesia). Basically, these problems will remain for SMEs remain. so it needs a straight line (main point) to be resolved, namely the aspect of Human Resources) one of which lies in the mindset (Mindset), which became the main competencies Soft Perpetrators of SMEs in developing navigate.
The problems of HR in SMEs is still unresolved for the SMEs is still at the fixed mindset, it is supported by the fact that an indicator of entrepreneurial characteristics of the lowest score was independent nature, nature loves a challenge and nature responsive to opportunities. This becomes a problem because the current conditions (current situation) has a gap with ideal conditions (Ideal Situation).

\section{Maintaining the Integrity of the Specifications}

This paper is based with the incorporation of research methodologies that Meta analysis and also integrating simplification theory (IST) using a critical review of sources such as journals and citation figures. Metaanalysis according to some experts, according Sugiyanto (2004) meta-analysis is the study by analyzing data derived from primary studies used as the basis for accepting or supporting the hypothesis, reject/abort the hypothesis proposed by previous researchers. methods of analysis using a number of the collected data and applying statistical methods of data with practice in organize amount of information coming from large samples whose function is to complement other purposes (Glass, 1981). Previous According Soekanto (1988) meta-analysis is the nature of this kind of analysis to obtain a series of information derived from a number of research data that already exists.

From some of the above, it can be concluded that research using meta-analysis is a study summarizing various studies pre existing quantitatively. In this context, the authors draw points in the writing paper using data gathered previously existing literature or critical review. How many papers?

The goal is to provide the same methodological rigor required libraries review of an investigation. Besides the research methodology is also combined with Simplification Integrating process which focuses on the theory and release simplifies the understanding of the complexity. Integration implies harmonization to the whole, a unity or common goal or higher purpose in this case is about aligning the direction of the vision of simplification. Simplifying the practice became common goal, aggregate, with or higher which in this case can harmonized needs and abilities. Integrating Simplification is a form of organizational innovation that enables organizations to operate in accordance with the focus. Serving accordance with their needs is the main driving force for this type of organization 
(Nandram and Bindlish, 2017). Managing VUCA Through Integrative Self-Management (Management for Professionals).

With the merger of the two cornerstone of this methodology the author tries to map the results of literature supports the future-dimensional relationship with the sub-level mindset ready concept to business transformations are matched up with VUCA characteristic to be able to resolve the fundamental problems that exist in the business practitioners.

\section{RESULTS}

The basic of problems that exist in businesses coupled with the turbulence that continuously occur caused by the transformation of the business ecosystem, the focus of the authors to be able to map the situation continues changes, uncertainty, complexity is high and too ambiguous to be materials and preparation for businesses so that they can survive in a state that is very disruptive.

Future-Ready Mindset be something that is very fundamental to be able to resolve problems that occur in businesses. Assuming, as entrepreneurs have come forward thinking patterns, dining will be a very positive thing for the survival and development efforts. Can understand shifting customer needs are constantly changing as well as identify new way of working that has a value of its own in order to accelerate their business performance.

Capabilities that can map business mindset transformation is judged to be a matter that should be resolved early. Future-Ready Mindset including Curiosity, seek to know the existence of previously unknown, always questioning things and seek to know the truth with supporting data or other literacy resources. With curiosity we become increasingly rich viewing angle and can determine the position to choose, reject, make a decision and take a stand. Hone critical thinking in order to more sharply browse for something. Second, the Explorer, in Cambridge Dictionary this word has a meaning someone who travels to places where no one has ever been in order to find out what is there. Meanings are trying author to convey that explore a strange thing and tries to learn and understand it well. Empathy, Rutherford, Baron-Cohen and Wheelwright
(2002) Noted that caring, concerned individual, and imagination are emotional components of empathy. An individual can place himself in the mental states of others, producing thoughts or feelings that are supportive of others. in another opinion empathy is the ability to feel, under standard define something that is happening around him. Empathy also becomes a very thin in the current era, given that most people become less concerned with the environment due to the very intense activity in cyberspace. while critical empathize the main basis so that businesses can rapidly responsive to changes allowed into the threat. When businesses can define a critical situation with the empathize, hereinafter he also had a transformative mindset to be able to continue to perform positioning, targeting and implementing of business. new strategies is also a supporter of the section's future-Ready Mindset. Barman and Potsangbam (2017), Transformational leadership is a theory of leadership where a leader works with teams to identify needed change, creating a vision to guide the change through inspiration, and executing the change in tandem with the dedicated members of a group (Odumeru and Ogbonna, 2013). Transformational vs. transactional leadership theories: Evidence in the literature.

Transformational leadership is when the leader behaviours influence followers and inspire them to perform beyond Reviews their perceived capabilities. Transformational Leadership Inspires people to Achieve unexpected or remarkable results. besides, it takes too experimental mindset, as we know that this foundation is needed to try to do the procedure can support, denied and also validate a hypothesis that in this context the world is very dynamic and constantly moving and changing fast. And the last is an open supporter of mindset which became an important foundation to blend in and accept all forms information then filtered. accept criticism, feedback, suggestions, opinions as the reinforcement of personal or business value.

The sixth foundation for the era disruptive thinking is then dissected and associated with each of the properties and sub-level concept. it is intended to provide an overview to understand and define the minimum requirements exist for business transformations era for business. then the author maps each element with the characteristics of the era VUCA so that businesses can adapt quickly and adjust the needs that must be held to maintenance or made more flexible to the challenge. 
The author collects a wide range of journals from many authors and researchers as reference material and also a supporter of the statement is classified by table. whether it is on the properties of the Future-Ready Mindset, sublevel contract and also navigate to VUCA Era (Table 1). In the research that already exists on the Future-
Ready Mindset associated with VUCA era to become a navigational or paths that are relevant. Growing body of literature that can be collected, it will strengthen the argument against the Future-Ready Mindset. even so, there will still always be changes even in this navigation model in accordance with the development era.

Table 1. Integrating Simplification Theory (IST) of Future Ready Mindset and VUCA

\begin{tabular}{|c|c|c|c|}
\hline $\begin{array}{l}\text { Core of Future } \\
\text { Ready Mindset }\end{array}$ & $\begin{array}{l}\text { Sub- element of } \\
\text { Mindset }\end{array}$ & Definition and Source of Papers & $\begin{array}{l}\text { Navigating } \\
\text { VUCA era }\end{array}$ \\
\hline \multirow[t]{2}{*}{ Curiosity } & $\begin{array}{l}\text { Never Stop } \\
\text { Learning }\end{array}$ & $\begin{array}{l}\text { A Combination of training, mentoring and executive coaching } \\
\text { (FMI, 2012) }\end{array}$ & Uncertain \\
\hline & Futurist & Comfortable with reality & Ambiguous \\
\hline \multirow[t]{6}{*}{ Open Mindset } & $\begin{array}{l}\text { Foresight and } \\
\text { Agility }\end{array}$ & $\begin{array}{l}\text { Ability to simultaneously manage both the } \\
\text { short-term the long-term goals of a business }\end{array}$ & Volatile \\
\hline & & $\begin{array}{l}\text { Create potential resources against potential } \\
\text { future }\end{array}$ & Ambiguous \\
\hline & & Monitor the latest Information & Ambiguous \\
\hline & $\begin{array}{l}\text { Develop Critical } \\
\text { Thinking }\end{array}$ & Think Different (FMI, 2012) & $\begin{array}{l}\text { Complexity \& } \\
\text { Ambiguous }\end{array}$ \\
\hline & $\begin{array}{l}\text { Cognitive } \\
\text { Flexibility }\end{array}$ & $\begin{array}{l}\text { The ability to addapt behaviours in response } \\
\text { changes in the environment (Handbook of Behavioural } \\
\text { Neouroscience, 2016) }\end{array}$ & Uncertain \\
\hline & $\begin{array}{l}\text { Think } \\
\text { Outrageously }\end{array}$ & $\begin{array}{l}\text { Thinking out of the box, openness to new ways of seeing the } \\
\text { world and a willingness to explore (Barman, 2017) }\end{array}$ & Ambiguous \\
\hline \multirow[t]{6}{*}{ Transformative } & $\begin{array}{l}\text { Business } \\
\text { modelling needs to } \\
\text { evolve }\end{array}$ & $\begin{array}{l}\text { Multitasking Abilities instilling among employees (Deepak, } \\
\text { 2019) }\end{array}$ & Volatile \\
\hline & $\begin{array}{l}\text { Transformation } \\
\text { Leader }\end{array}$ & $\begin{array}{l}\text { - The idealized /charismaticinfluence. } \\
\text { - Inspiration a motivation. } \\
\text { - Intellectualstimulation. } \\
\text { - Individualized consideration }\end{array}$ & Uncertain \\
\hline & & $\begin{array}{l}\text { Ability to fathom the core operations of the } \\
\text { business (Deepak, 2019) }\end{array}$ & Volatile \\
\hline & $\begin{array}{l}\text { Design } \\
\text { Organization's } \\
\text { Capability }\end{array}$ & Sustain an adaptive and productove organizational culture & Ambiguous \\
\hline & $\begin{array}{l}\text { Consumer } \\
\text { Centricity }\end{array}$ & $\begin{array}{l}\text { Use human- centred processes, such as observation and } \\
\text { questioning, to collect insights; use visual thinking and } \\
\text { storytelling skills to share hypotheses and ideas quickly } \\
\text { intervening and Effectively; }\end{array}$ & Complexity \\
\hline & & $\begin{array}{l}\text { Learn how to observe your Objectively and see things from a } \\
\text { customer's perspective (Singularity University 2018) }\end{array}$ & Volatile \\
\hline Experimental & $\begin{array}{l}\text { Collaborative } \\
\text { and Constantly } \\
\text { Test New ideas }\end{array}$ & Establish Innovation Network (Fontana, 2016) & Complexity \\
\hline Explorer & $\begin{array}{l}\text { Attracting } \\
\text { Great Talent }\end{array}$ & $\begin{array}{l}\text { Abillities for exploring problems and possible solutions in new } \\
\text { and creative ways }\end{array}$ & Complexity \\
\hline \multirow[t]{2}{*}{ Emphaty } & $\begin{array}{l}\text { Emotional } \\
\text { Intelligent }\end{array}$ & Decision Making, Solves Problem (Juheo, 2017) & Uncertain \\
\hline & & Be Able to tune into others and factor reactions (Juhro, 2017) & Ambiguous \\
\hline
\end{tabular}




\section{Managerial Implications}

Since there are 6 (six) cores Future-Ready Mindset, each business should apply at least, one of these cores for their business production process. In this disruptive era, curiosity has become on of the cores. That is why, nowadays customer never stops learning, they want more and more to learn about all their product in details. It can be seen from recent cosmetics products that have mentioned their active ingredients as the title of the product, not only the benefit of the product. They now prefer the branding of niacinamide rather than whitening cream. This thing can be applied not only for cosmetics products, but all product lines. Consumers nowadays also want to be a center of business attention. The transformation core makes the system of business becomes Customer Centralized. It is more like storytelling skill and getting customer's point of view is as important as the quality of the product itself.

\section{CONCLUSIONS AND RECOMMENDATIONS}

\section{Conclusions}

To navigate its transformation path, the future ready mindsets - curiosity, explorer, empathy, transformative, experimental, and open mindset - will play a crucial part. Sub-concepts for each of the future-ready mindset have already been mapped and matched up with each VUCA characteristic.

\section{Recommendations}

Based on the research, a person who navigates a Business must have a combination of core elements of Future-Ready Mindset, especially on the VUCA era. Everything is dynamic and unpredictable; by preparing Future-Ready Mindset we can reduce risk, create an opportunity from a threat of this disruptive era. The results of this study can be a reference for stakeholders either the government in making policies, the Business community or further researches

\section{REFERENCES}

Barman A, Potsangbam C. 2017. Shift of strategic paradigms in the VUCA World- Does "outside the box thinking" a meaningful cliche for the business world?, Conference: Managing Change and Creativity and Innovation in a Dynamic Environment at Sonapur, Kolkata, Vol. 7th and 8th.

Bar-On R. Parker JDA. 2000. The handbook of emotional intelligence. San Fransisco, CA: Jossey-Bass Inc.

Codreanu A. 2016. A VUCA action framework for a VUCA environment leadership challenges and solutions. Journal of Defense Resources Management 7(2): 31-38.

Deepak S, Parween S. 2019. Positioning the future of Human Resource Management in a VUCA world.

Fauji E. Analisis karakteristik pelaku UMKM (Usaha Mikro Kecil Menengah) di Kota Kediri. Kediri: Fakultas Ekonomu Universitas Nusantara PGRI Kediri.

FMI Corporation. 2012. Redefining Leadership: Strategic thinking in today's VUCA World. NC; FMI Coroporation.

Gentry WA, Todd JW, Golnaz S. 2007. Emphaty in the workplace a tool for effective leadership, The Society of Industrial Organizational Psychology Conference, New York.

George JM. 2000. Emotions and leadership: The role of emotional intelligence. Human Relations 53: 1027-1055.

Joel, Michelle L. 2001. Navigating skills for thriving in "VUCA" times, Summer Institute, [http://www. wisdomatwork.com/about/thriving-in-vucatimes/], 2011.

Juhro SM. 2017. Transformational Leadership: Chopping with The Challenges in VUCA Environment, An Applied Neuroscience Perspective, Proceeding; Bank Indonesia Seminar. Jakarta: Bank Indonesia Institut.

KramerJ,AgoginoAM,RoschuniC.2016.Characterizing competencies for Human-Centered Design, International Design Engineering Techincal Conferences and Computers and Information in Engineering Conference, ASME.

Millar CCJM, Groth O, Mahon JF. 2018. Management Innovation in a VUCA world. Challenges and Recommendations, California Management Review 61(1): 5 - 14.

Orejarena H, Zambrano O, Carvajal M. 2019. Emotional intelligence and its influence on organizational leadership in the VUCA world. Advances in Social Science, Education and Humanities Research 359:185-188.

Parween S. 2019. Positioning the future of Human 
ResourceManagementinaVUCAWorld",[https;// www.researchgate.net/publication/333673492 Positioning_The_Future_Of_Human Resource_In_A_VUCA_World].

Raghuramapatruni R, Kosuri SR. 2017. The Straits of Success in a VUCA World, IOSR Journal of Business and Management (IOSR-JBM), IES Management College and Research Centre (IESMCRC-2017), pages 16-22.
Solomon LK. 2017. A Framework for leading in today's world. USA: Singulaity University.

Suryana 2003. Kewirausahaan: Pedoman praktis kiat dan proses menuju sukses. Jakarta: Salemba Empat.

United Nations Development Programe. 2019. Human Development Index and Its Component. [United Nations Development Programe 2019]. 